\title{
The Influence of Water/Binder Ratio on the Mechanical Properties of Lime-Based Mortars with White Portland Cement
}

\author{
Dejan Vasovic *, Jefto Terzovic, Ana Kontic, Ruza Okrajnov-Bajic and Nenad Sekularac \\ Faculty of Architecture, University of Belgrade, 11000 Belgrade, Serbia; jefto@arh.bg.ac.rs (J.T.); \\ an.ko@arh.bg.ac.rs (A.K.); ruza@arh.bg.ac.rs (R.O.-B.); nenad.sekularac@arh.bg.ac.rs (N.S.) \\ * Correspondence: d.vasovic@arh.bg.ac.rs; Tel.: +381-631-119-838
}

check for

updates

Citation: Vasovic, D.; Terzovic, J.; Kontic, A.; Okrajnov-Bajic, R.; Sekularac, N. The Influence of Water/Binder Ratio on the Mechanical Properties of Lime-Based Mortars with White Portland Cement. Crystals 2021, 11, 958. https:// doi.org/10.3390/cryst11080958

Academic Editors: Antonella Sola, Sumit Chakraborty, Valentina Volpini and Cesare Signorini

Received: 18 July 2021

Accepted: 14 August 2021

Published: 16 August 2021

Publisher's Note: MDPI stays neutral with regard to jurisdictional claims in published maps and institutional affiliations.

Copyright: (c) 2021 by the authors. Licensee MDPI, Basel, Switzerland. This article is an open access article distributed under the terms and conditions of the Creative Commons Attribution (CC BY) license (https:/ / creativecommons.org/licenses/by/ $4.0 /)$.

\begin{abstract}
Protecting the built cultural heritage is one of the most important tasks in architectural practice. The process of repair is time-consuming, weather-dependent, and sensitive to materials applied. Introducing new materials in historic building repair in order to decrease the time needed for repair, brings some risk in the preservation process. The most common material for masonry repair is lime mortar. Adding cement to lime mortar can improve the mechanical properties of mortar and speed up the repair process. The high amount of cement may increase the strength, but decrease ductility and permeability of mortar, causing damages to protected buildings. An increase in strength with the smallest amounts of cement demands optimization of water content in the mixture. Tests were performed to investigate the influence of the water/binder $(\mathrm{w} / \mathrm{b}=$ water $/($ lime + cement $)$ ratio on mortar strength and water permeability. An air-entraining agent (AEG) was introduced to improve permeability. Results confirmed that adding small amounts of cement to lime ( $20 \%$ by weight) and decreasing of $\mathrm{w} / \mathrm{b}$ ratio, improves the strength, with almost negligible influence on water permeability. The addition of very small amounts of AEG did not decrease the strength, nor the permeability.
\end{abstract}

Keywords: lime-cement mortar; compressive strength; air-entrained agent; heritage conservation; reconstruction and restoration of historical buildings

\section{Introduction}

Historical buildings have cultural significance, witness to architectural history, but also preserve information about structural systems, materials applied and building techniques used [1]. Until the end of the 18th century, the use of lime mortar was considered as an element of continuity of architectural heritage, whether it was applied for rendering or as a structural component. The oldest data, from 6000 BC (before Christ) regarding the application of lime in Serbia, is located in Lepenski Vir, an archaeological site from the Neolithic era on the banks of the Danube River, where the lime mortar floor, made with quicklime, was found [2]. The process of lime mortars hardening, i.e. transformation of $\mathrm{Ca}(\mathrm{OH})_{2}$, into $\mathrm{CaCO}_{3}$ as a carrier of strength, occurs in the presence of carbon dioxide. According to Van Balen [3], diffusion of $\mathrm{CO}_{2}$ is roughly 10,000 times lower in water than in air [4,5]. Literature review [6-10], has shown that after 180 days from the production day, lime mortar reaches approximately the final values of its compressive strength. Elongated setting and requirements for dry environmental conditions, slow and undetermined carbonation, low mechanical properties, and internal cohesion, were the main reasons for the introduction of Portland Cement (PC) into conservation practice. Lime and alumina silicates in cement develop crystalline substances during hydration which improves the strength of mortar and its adhesion to the brick and stone. [11]. Nevertheless, as conservation of historic structures is quite complex and its accomplishment lies in the adequate interaction between the inherited structure and a new one, the rapid diffusion of PC was stopped because of its incompatibility with the original structure. A high concentration of soluble salts found in PC could cause damage to the original materials as salt 
crystallization occurs. Moreover, higher mechanical strengths of the PC than of the original mortar, as well as low deformability, appeared to be the source of degradation of historical heritage. International organizations, such as International Council on Monuments and Sites (ICOMOS) or International Centre for the Study of the Preservation and Restoration of Cultural Property (ICCROM), prefer practitioners to use the same or materials similar to originals, both in composition and characteristics, for the restoration works $[7,12]$.

Research problems in the area of mechanical characteristics of lime-based mortars are various, moving from deeper exploration and understanding of carbonation process $[3,8,13,14]$, different factors affecting it [15-17], to studies focusing on mechanical characteristics of the final product with different variables [7,18-28]. However, the addition of cement to lime-based mortars is still a common practice in most conservation works in order to increase the hardening reaction by cement hydration [29].

Long-term exposure to environmental loads damage and decay the walls of the historical buildings. Mortar for the restoration of the walls of historical monuments should bind the masonry elements (stone, brick) into a sound structure providing load-bearing capacity in the shortest possible time, while its compressive and tensile strengths must not be higher than those of the stone or brick, so that future environmental loads should damage restored mortar first, instead of the stone or brick that we want to protect. The adhesion of mortar should be lower than the tensile strength of the base material, to ensure the separation of the mortar from stone and brick instead of the crushing and falling stone or brick pieces together with the binder.

Figure 1 shows the retaining wall of a 14th-century fortification in the south of Serbia. Figure 1a was taken before the reconstruction in 2012 and shows the condition of the damaged wall: after several hundred years, the stones show no visible signs of damage; the white lime mortar that it had been built with collapsed because it had weaker mechanical properties. The wall was repaired with mortar containing a large amount of ordinary grey Portland cement (OPC). After hardening, this mortar had an inappropriate colour (as the white colour was requested by Heritage Protection Authorities), became significantly stronger and more impermeable than stone. The idea that stronger mortar will better strengthen the wall proved to be completely wrong. Figure 1 b, taken in 2021, less than nine years after the reconstruction, shows the consequences of the application of the inappropriate mortar: the stone is damaged and the surface layer, few centimetres thick, fell off. Significantly reduced permeability of the mortar caused the transport of water vapour and moisture through the stone material instead of through the mortar and resulted in accelerated deterioration of the stone wall.

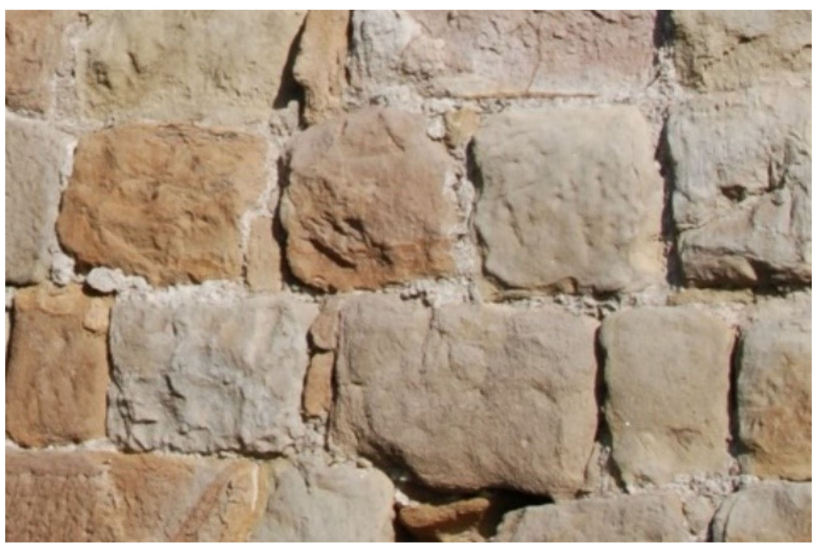

(a)

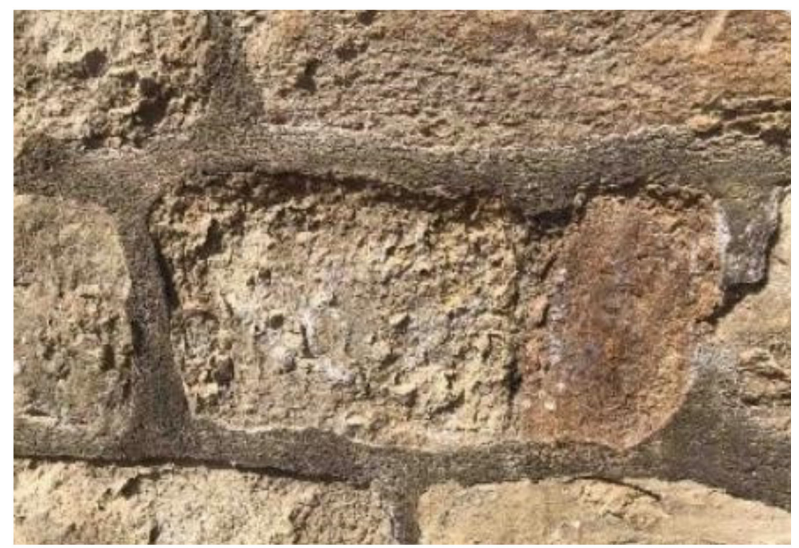

(b)

Figure 1. Malpractice of introducing cement-lime mortar in Serbia (a) before July 2012; (b) nine years after repair of the wall-July 2021). 
Many researchers are trying to define an adequate proportion of cement, to improve lime mortar properties, keeping its compatibility with historic structures. Nevertheless, it has been found that by blending cement with the lime, it is possible to reduce cracking, to quicken the application and hardening of the mortar, thus providing protection from the rain before carbonation has been completed, and to ensure reliability and predictability of its properties [30]. Literature review regarding the issue of adding PC to lime mortars shows that there are no clear recommendations. Some studies promote the use of PC to a significant extent of a minimum of $20 \%$ of lime weight, justifying it by high initial strengths $[11,19]$. Other studies promote the use of PC in smaller amounts, referencing unchanged water absorption with regard to lime mortars with no additives [31], significant reduction of porosity due to the increase of cement content [29], or loss of elastoplastic behaviour or mortar mixtures, which makes them able to adapt to movements and deformation under critical stress in the masonry [32].

It is notable, that the information available regarding this topic is diversified, with no unique attitude concerning the optimum amount of Portland cement in lime-based mortars. Literature review showed that criteria of water/binder ratio in lime mortars with the addition of cement, is quite neglected, therefore, this paper aims at discussing early mechanical properties (up to 28 days) of the abovementioned mixtures. It is well known that the water/binder ratio in cement mortars has a strong influence on the mechanical characteristics of the hardened material. However, this rule is not applicable to lime mortars, due to smaller particle size. Research made by Lawrence and Walker [33], demonstrates that the water/binder ratio has almost no influence at all on the mechanical properties of lime mortars. On the other hand, according to Lanas and Alvarez [7], a higher water/binder ratio results in greater porosity, which enables better diffusion of $\mathrm{CO}_{2}$, a key component in the process of carbonation. Hence, the main hypothesis of this paper is that with an adequate determination of water/binder ratio in lime mortars with the addition of White Portland Cement (WPC), higher initial mechanical strengths could be acquired with amounts of cement, up to $20 \%$ of the lime weight. Use of the WPC is mandatory, as heritage protection requirements demand the white colour of the mortar.

The literature reviews also showed different studies of lime mortars with incomparable mixtures. Some mixture proportions are determined by weight, others by volume; some use hydrated lime in powder, others, lime putty. However, the water content of the mixtures is determined arbitrarily: "on the basis of masonry experience", "adequate for common workability", by volume or by weight of binder (regardless of the lime/cement ratio), etc. Such determination of water content is especially inadequate when cement is added. Excessive water may prevent the expected cement hardening. The mechanical characteristics of cement-based mortars and concrete crucially depend on the W/C factor. It is, therefore, necessary to precisely define the amount of water in lime mortar with the addition of cement. This study shows that it is necessary to keep the same consistency of the lime-cement mortars mixtures, in order to adequately compare their mechanical properties.

\section{Materials and Methods}

\subsection{Composition of Mortar Mixtures}

Mortars were made by using the following components:

- Hydrated lime CL90-S (EN 459-1, produced by Ingram, Bosnia, and Herzegovina).

- Calcium carbonate aggregate produced by OMYA (Venčac, Serbia); it was used in two grades (0.0-0.8 $\mathrm{mm}$ and $0.8-2.0 \mathrm{~mm})$, equally dosed.

- Lime/Aggregate ratio was defined among the commonest dosages described in the literature, as 1:3.

- WPC CEM I $52.5 \mathrm{~N}$ was used (EN 197-1, produced by CRH Slovakia). Different amounts of WPC were added, as shown in Table 1. 
Table 1. Mortar mixtures and properties of fresh mortars.

\begin{tabular}{|c|c|c|c|c|c|c|c|}
\hline Series & $\begin{array}{l}\text { Specimen } \\
\text { Code }\end{array}$ & $\begin{array}{c}w / b \\
\text { Ratio }\end{array}$ & WPC & $\begin{array}{c}\text { Lime/WPC } \\
\text { (by Weight) }\end{array}$ & $\begin{array}{l}\text { AEG/WPC } \\
\text { (by Weight) }\end{array}$ & Slump Flow (mm) & Slump (mm) \\
\hline 1 & $\mathrm{E}$ & 0.875 & - & - & - & 68.0 & 5 \\
\hline 1 & C5 & 0.875 & WPC & $5 \%$ & - & 80.0 & 10 \\
\hline 1 & C10 & 0.875 & WPC & $10 \%$ & - & 87.5 & 16 \\
\hline 1 & $\mathrm{C} 20$ & 0.875 & WPC & $20 \%$ & - & 91.0 & 17 \\
\hline 2 & KC5 & 0.845 & WPC & $5 \%$ & - & 71.5 & 9 \\
\hline 2 & KC10 & 0.8125 & WPC & $10 \%$ & - & 70.0 & 9 \\
\hline 2 & KC20 & 0.755 & WPC & $20 \%$ & - & 68.0 & 9 \\
\hline 3 & AC5 & 0.845 & WPC & $5 \%$ & $0.4 \%$ & 75.5 & 10 \\
\hline 3 & AC10 & 0.8125 & WPC & $10 \%$ & $0.4 \%$ & 75.0 & 10 \\
\hline 3 & AC20 & 0.755 & WPC & $20 \%$ & $0.4 \%$ & 78.5 & 11 \\
\hline
\end{tabular}

Table 1 shows mixture proportions and properties of one reference (E) and nine different mixtures in three series $(C, K C$, and $A C)$ that were made. Six specimens of each mixture were casted (three for testing after 7 and three for testing after 28 days).

- $\quad$ Series 1 , with $\mathrm{w} / \mathrm{b}$ ratio at fixed value (0.875);

- Series 2 , with $\mathrm{w} / \mathrm{b}$ ratio at three different values, but same workability (slump);

- Series 3, with the same workability (slump), but with the added air-entraining agent (AEG-Chryso Air G 100, 0.4\% by weight of cement).

The amount of water added $(\mathrm{w} / \mathrm{l}=0.875)$ for the reference lime mortar $(\mathrm{E})$ was based on experience. The first series of samples were casted with the same water/binder ratio, which increased the slump. In order to obtain the same slump, in series 2 and 3, the water/binder ratio was decreased.

Mixtures were prepared following European standard EN 196-1. Binders were mixed with water for $1 \mathrm{~min}$, the aggregate was added, and mixed for 2 minutes. Afterwards, the prepared paste was casted in moulds, dimensions $40 \times 40 \times 160 \mathrm{~mm}$, and covered with absorbent paper in order to decrease evaporation.

The specimens were cured under dry environment conditions $\left(\mathrm{T}=20 \pm 5{ }^{\circ} \mathrm{C}\right.$, $\mathrm{RH}=65 \pm 5 \%$ ), removed from moulds after 5 days (as reference samples did not gain sufficient strength to be removed earlier), and tested on the 7th and 28th day.

\subsection{Methods for Measurement of Properties of Hardened Mortars}

2.2.1. Compressive Strength

Compressive strength was measured in accordance with European standard EN 101511 using CONTROLS Pilot Pro Multipurpose 500/15 kN Cement Compression and Flexural Machine, with a loading rate of $40 \mathrm{~N} / \mathrm{s}$.

\subsubsection{Flexural Strength}

A three-point flexural test was performed using CONTROLS Pilot Pro Multipurpose 500/15 kN Cement Compression and Flexural Machine, with the loading rate of $1 \mathrm{~N} / \mathrm{s}$.

\subsubsection{Carbonation Depth}

A carbonation depth test was performed using phenolphthalein on the broken surfaces of the specimens, immediately after the flexural test. Phenolphthalein indicated the development of carbonation, as it changed the colour from colourless to purple at $\mathrm{pH}>9$, in the presence of $\mathrm{OH}^{-}$ions. This method, although not very precise, was chosen as the fastest and easily visible. Other more precise methods for measuring the carbonation depth (X-ray Diffraction Analysis, Fourier Transform Infrared Spectroscopy, Thermo-gravimetric Analysis and Loss on Ignition, Dust digestion [34] required special equipment and trained professionals for the application, to which the authors had no access. 


\subsubsection{Capillary Absorption}

The capillary absorption tests were conducted in accordance with European standard EN 1015-18, by placing the specimens in shallow water, around $3 \mathrm{~mm}$ depth. The weight of specimens was taken in different time intervals, at 1,3, 5, 10, 15, 20, 30, 45, 60, 90, 120, and $150 \mathrm{~min}$, until the absorption reached an asymptotic value.

\section{Results}

Results of compressive and flexural strength testing after 7 and 28 days are shown in Table 2. Values in Table 2 are average values of three specimens for flexure, and six specimens for compressive strength. It shows that the addition of WPC in the range of $20 \%$ (specimens $\mathrm{C} 20, \mathrm{KC} 20$, and $\mathrm{AC} 20$ ) improves compressive strength in comparison to the reference mortar (E).

Table 2. Average compressive $\left(f_{c}\right)$ and flexural strength $\left(f_{f}\right)$, at 7 and 28 days, with their corresponding standard deviation $(\sigma)$.

\begin{tabular}{cccccccccc}
\hline & & \multicolumn{3}{c}{ Compressive Strength, $f_{c}(\mathbf{M P a})$} & \multicolumn{3}{c}{ Flexural Strength, $f_{f}(\mathbf{M P a})$} \\
\cline { 3 - 9 } Series & Specimen Code & \multicolumn{2}{c}{ 7 Days } & \multicolumn{2}{c}{ 28 Days } & \multicolumn{3}{c}{ 7 Days } & 28 Days \\
\cline { 3 - 9 } & & $f_{c, 7}$ & $\sigma$ & $f_{c, 28}$ & $\sigma$ & $f_{f, 7}$ & $\sigma$ & $f_{f, 28}$ & $\sigma$ \\
\hline 1 & E & 0.580 & 0.056 & 1.515 & 0.131 & 0.145 & 0.022 & 0.300 & 0.029 \\
1 & C5 & 0.430 & 0.032 & 1.125 & 0.051 & 0.160 & 0.024 & 0.335 & 0.060 \\
1 & C10 & 0.540 & 0.079 & 1.315 & 0.065 & 0.185 & 0.029 & 0.340 & 0.062 \\
1 & C20 & 0.940 & 0.028 & 1.705 & 0.109 & 0.325 & 0.051 & 0.525 & 0.041 \\
\hline 2 & KC5 & 0.910 & 0.050 & 1.425 & 0.094 & 0.130 & 0.017 & 0.460 & 0.037 \\
2 & KC10 & 0.940 & 0.038 & 1.100 & 0.131 & 0.130 & 0.021 & 0.505 & 0.029 \\
2 & KC20 & 1.430 & 0.071 & 2.020 & 0.112 & 0.145 & 0.021 & 0.535 & 0.037 \\
\hline 3 & AC5 & 0.795 & 0.051 & 1.415 & 0.061 & 0.150 & 0.140 & 0.465 & 0.027 \\
3 & AC10 & 0.820 & 0.056 & 1.620 & 0.140 & 0.185 & 0.190 & 0.510 & 0.037 \\
3 & AC20 & 1.345 & 0.063 & 2.135 & 0.093 & 0.455 & 0.310 & 0.520 & 0.036 \\
\hline
\end{tabular}

\subsection{Compressive Strength}

The testing of specimens from Series 1 (Figure 2), with a constant water/binder ratio, shows that the addition of $5 \%$ of WPC reduces compressive strength by $27 \%$, whilst the addition of $10 \%$ of WPC reduces it by $36 \%$. Significant change occurs with the addition of WPC of $20 \%$, where the increase is more than $120 \%$ for the initial, 7 -day compressive strength, comparing to the reference specimen (E) without WPC. This trend of insignificant change of mechanical strengths with smaller additions of WPC ( $5 \%$ and 10\%), can be noted throughout results from all series. This observation is in accordance with results obtained from previous studies [11,19].

When it comes to water/binder ratio, by comparing results obtained from Series 1 (Figure 2) and Series 2 (Figure 3), it can be concluded that decreasing of water content in lime mortars with the addition of WPC, can have a major impact on the initial mechanical strengths. In order for the mixtures with the addition of cement to have the same consistency as the reference mixture (mixture E), it was necessary to reduce the total amount of water with the increase in the amount of added cement. This is notable for both 7th day and 28th-day strengths. In relation to results from Series 1, results from Series 2 show higher strengths, increasing as the amount of WPC increases, which was expected. It can be concluded that the addition of $20 \%$ of WPC, with a water binder ratio of 0.775 , increases compressive strength by $90 \%$ in the first 7 days, and by $60 \%$ on the 28 th day. The test results of KC10 samples with 10\% WPC, showed an unexpected decrease in strength, which may be due to internal defects. 


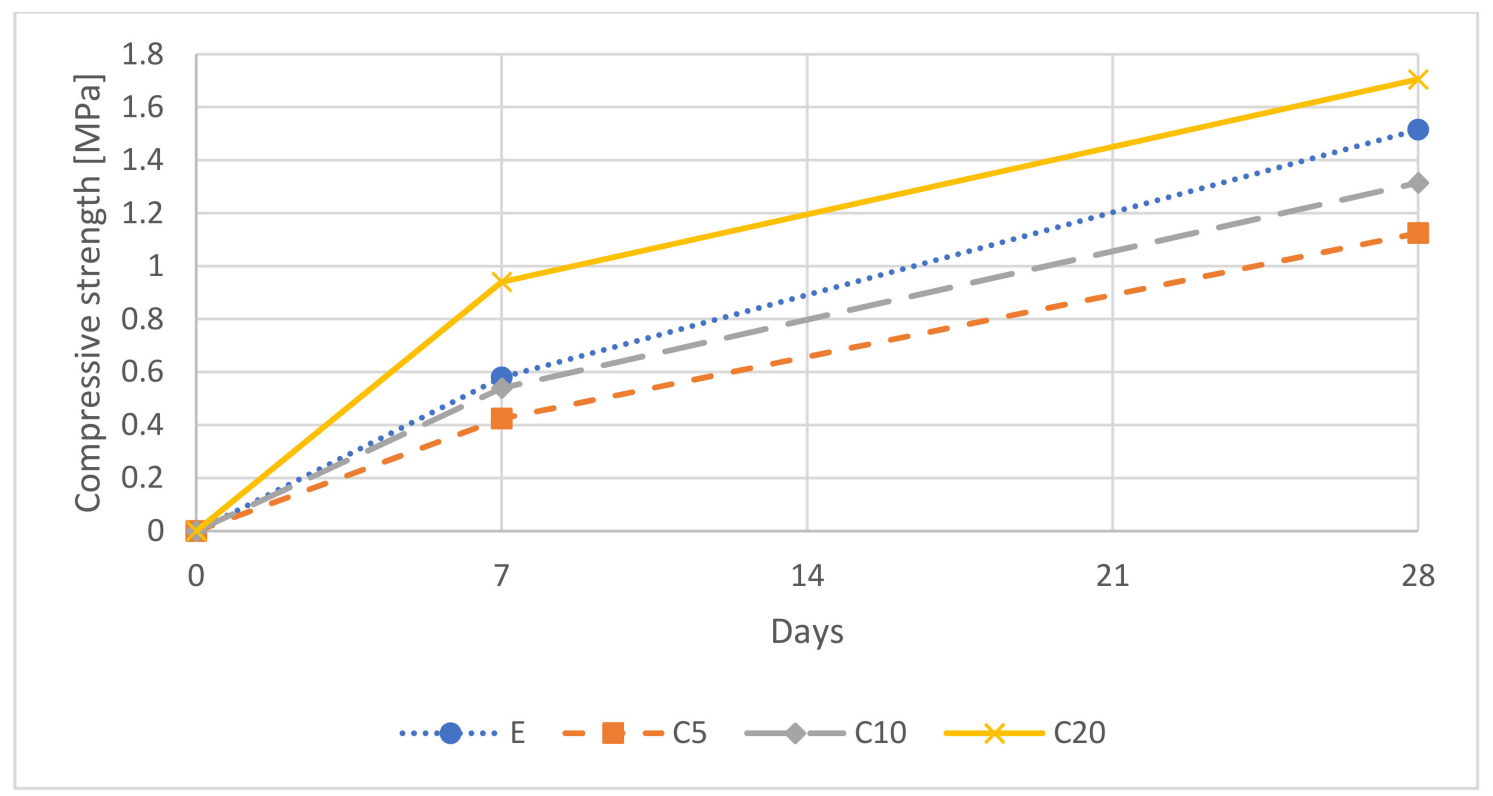

Figure 2. Development of compressive strength from 7-28 days in Series 1 (same w/b ratio, different percentage of WPC).

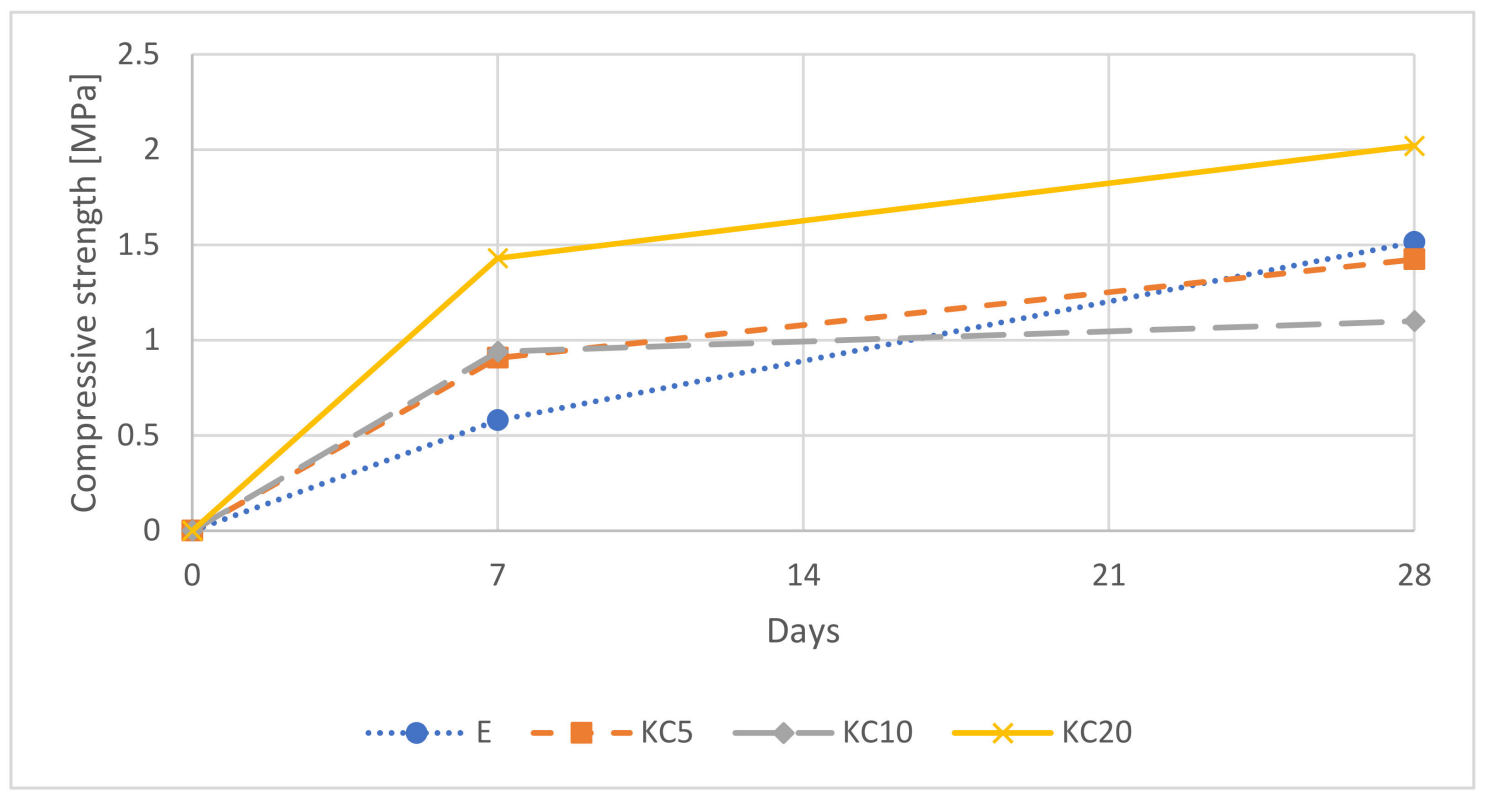

Figure 3. Development of compressive strength from 7-28 days in Series 2 (varied w/b ratio and percentage of WPC).

The main idea behind the addition of air-entraining agents (AEG) in the amount of $0.4 \%$ of WPC amount, was an increase of porosity as the addition of WPC decreases it. As the addition of AEG was the only variable between Series 2 and Series 3 specimens, it was expected that this addition would reduce mechanical strengths, but the result showed that this mixture gave almost the same results as the previous ones (Figure 4). The highest 28th-day compressive strength $(2.135 \mathrm{MPa})$ was for a specimen named AC20, with $20 \%$ WPC and $0.4 \%$ of AEG by weight of WPC. Concluding from the experiment, the addition of AEG does not reduce the compressive strength of lime mortars with the addition of WPC. 


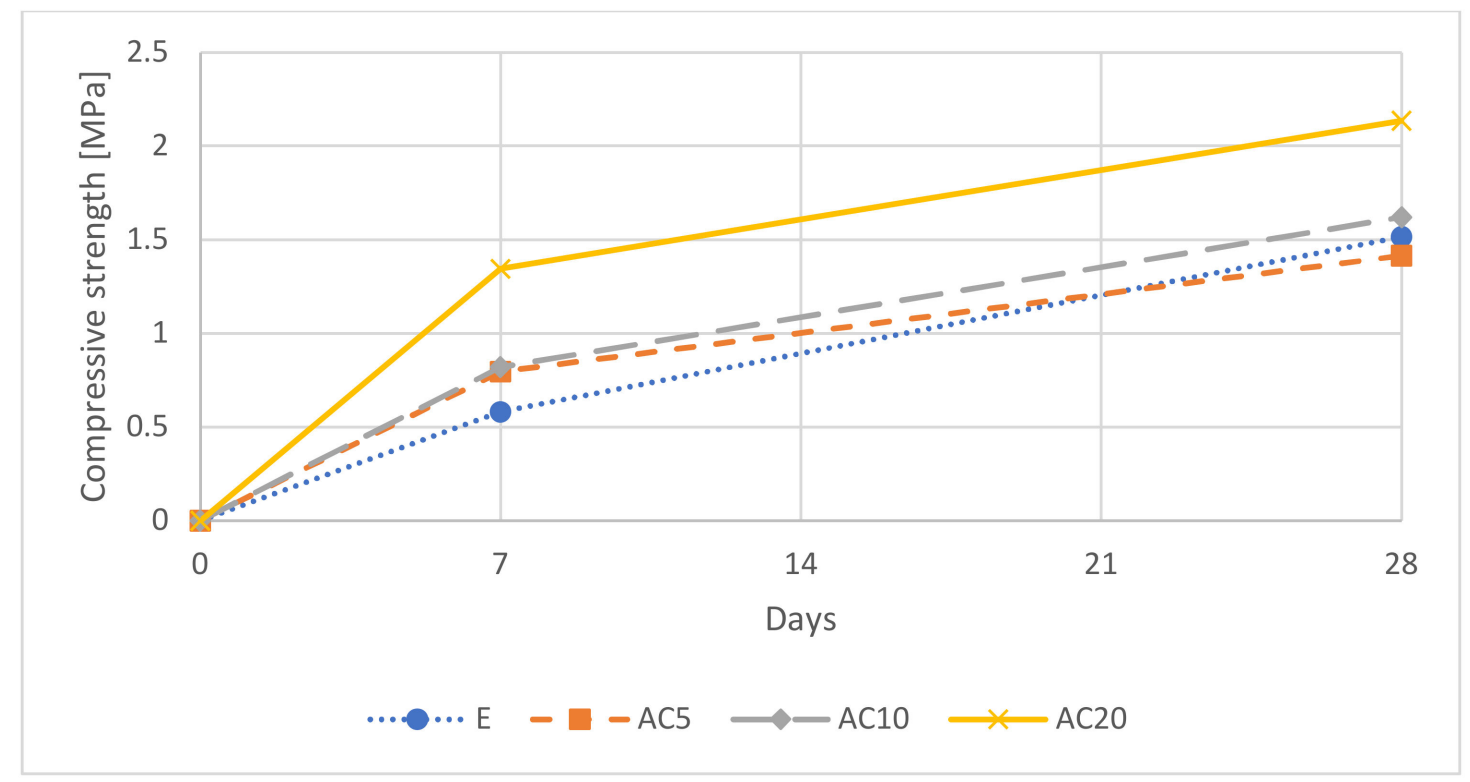

Figure 4. Development of compressive strength from 7-28 days in Series 3 (varied $\mathrm{w} / \mathrm{b}$ ratio and percentage of WPC, $0.4 \%$ AEG agents added).

\subsection{Flexural Strength}

It is noticeable that the addition of $5-10 \%$ of WPC to lime mortar slightly improves the flexural strength compared to the reference mortar (E) (results in Table 2). Regarding the specimens from Series 1 (Figure 5), with a constant water/binder ratio, it can be observed that the addition of $5 \%$ of WPC increases flexural strength by $28 \%$, whilst the addition of $10 \%$ of WPC, increases it by $48 \%$. Significant change occurs with the addition of WPC of $20 \%$, where the increase is more than $250 \%$ for the initial 7-day compressive strength, regarding the reference specimen with no WPC added. The abovementioned trend, of a slight change of mechanical strengths with the addition of WPC between $5-10 \%$, is diagnosed for flexural strength, as well.

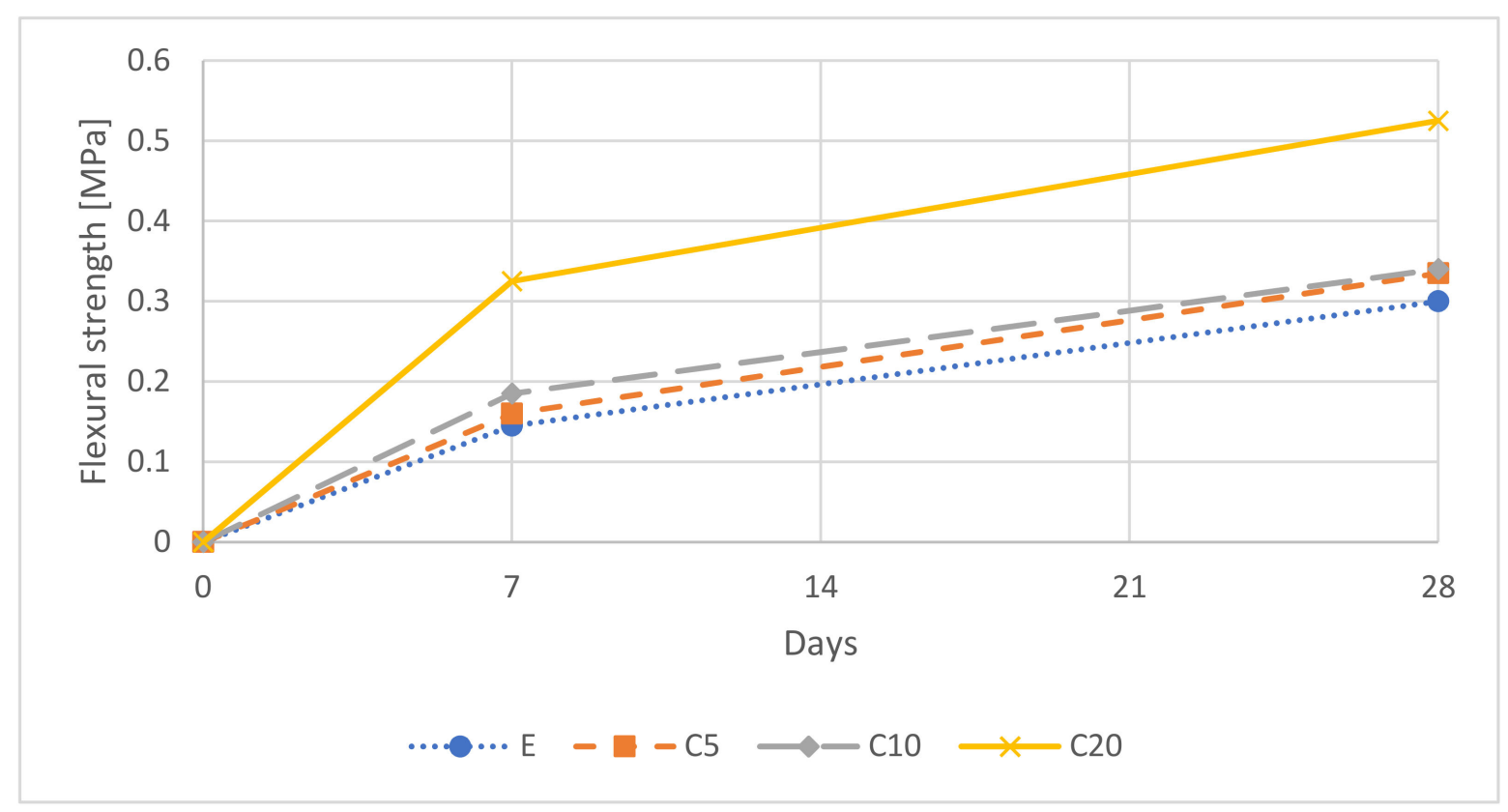

Figure 5. Development of flexural strength from 7-28 days in Series 1 (same w/b ratio, different percentage of WPC). 
With regard to water/binder ratio, comparing results obtained from Series 1 and Series 2 (Figure 6), it can be concluded that decreasing of water content in lime mortars with the addition of WPC, had a small influence only on 28th-day strengths, but did not improve the 7th-day strengths. It can be noted that an increase in the amount of WPC, slightly increases the flexural strengths of specimens.

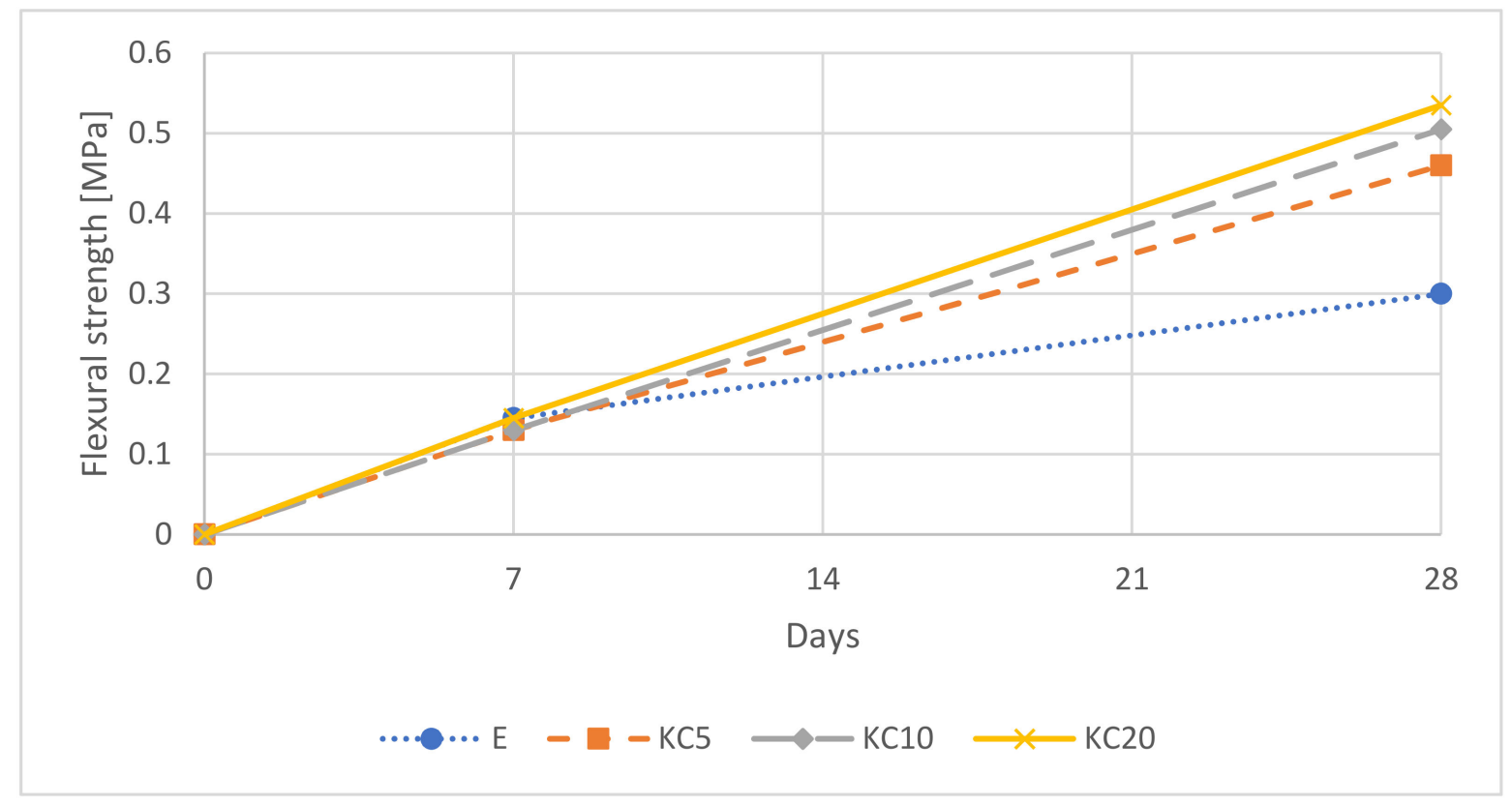

Figure 6. Development of flexural strength from 7-28 days in Series 2 (varied w/b ratio and percentage of WPC).

As for the specimens from Series 3 (Figure 7), the same trend can be noticed. The addition of AEG actually had no impact on flexural strengths, in comparison to the mixtures with no AEG added (Series 2).

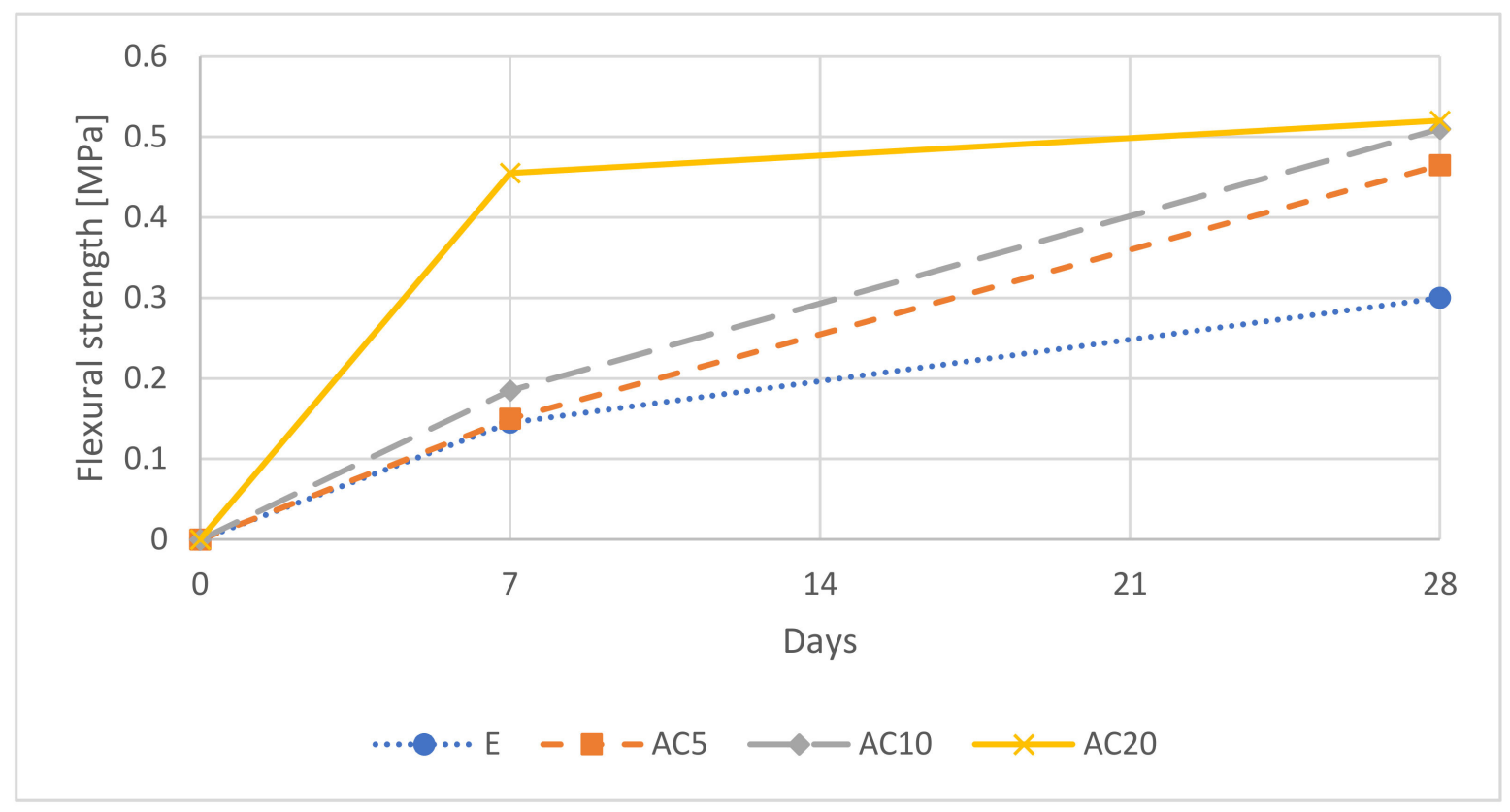

Figure 7. Development of flexural strength from 7-28 days in Series 3 (varied $\mathrm{w} / \mathrm{b}$ ratio and percentage of WPC, $0.4 \%$ AEG agents added). 


\subsection{Carbonation Depth}

Carbonation depth, determined by the phenolphthalein test after 28 days, showed that carbonation progressed from exterior to interior, but the measurement showed negligible differences between different specimens. For specimens with the addition of WPC, hardening is a result of two processes, carbonation of lime and hydration of cement. The result of these two processes can be seen by comparing specimens KC5, KC10, KC20 (Figure 8), where the increase of WPC amount decreases the carbonation depth.

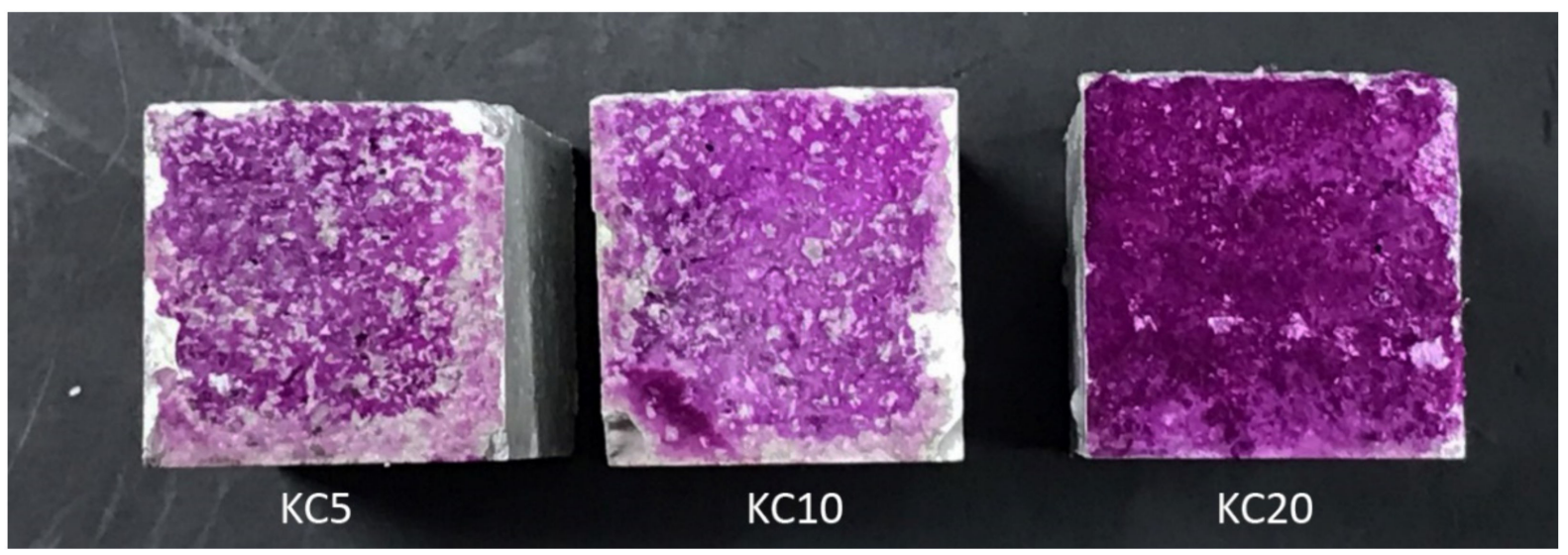

Figure 8. Phenolphthalein test specimens in Series 2 (varied $\mathrm{w} / \mathrm{b}$ ratio and percentage of WPC).

With the decrease of WPC, the effect of both the carbonation and hydration process is apparent. It is expected that carbonation will proceed gradually until the 180th day of the porosity. Results from specimens with the addition of AEG show different patterns, with gradual carbonation in the core, as well as by the edges (Figure 9).

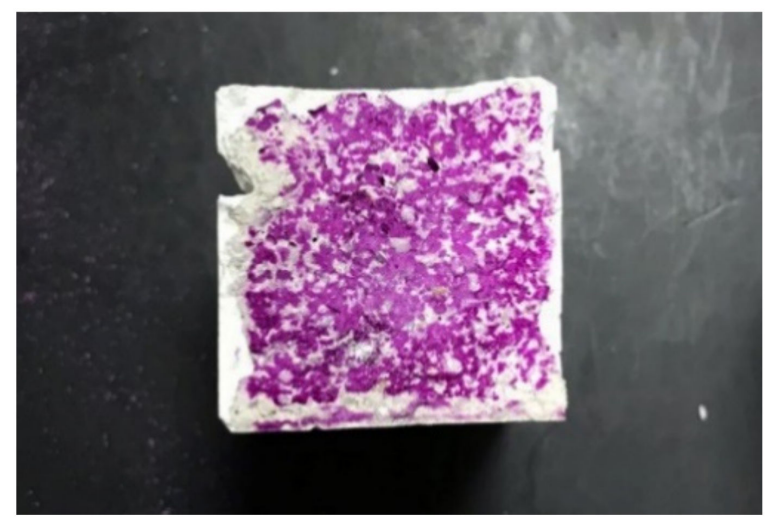

Figure 9. Phenolphthalein test, AC20 specimen (varied w/b ratio and percentage of WPC, $0.4 \%$ AEG agent added).

\subsection{Capillary Absorption}

Measured values of capillary absorption are shown in Table 3. It is commonly observed that the addition of WPC decreases the capillary absorption coefficient as a result of the changed pore structure. Results obtained from this research shows an insignificant change in capillary water absorption between different mixtures.

Although a test of porosity was not a part of this research, capillary water absorption results indicated that small amounts of WPC did not change capillary pore structure, as the absorption coefficient did not change significantly. For specimens with a constant water/binder ratio, the percentage of water absorbed was slightly increased. This is probably due to the fact that excess water in these mixtures resulted in greater porosity than for mixtures with constant consistency, where less water was used, thus, lower porosity was obtained. Results are shown in Figures 10 and 11. 
Table 3. Capillary water absorption: mass of the specimens $(m)$, mass of the absorbed water $(\Delta m)$, and its corresponding standard deviation $(\sigma)$.

\begin{tabular}{|c|c|c|c|c|c|c|c|}
\hline Series & Specimen Code & $m(\mathrm{~g})$ & $\Delta m(\mathrm{~g})$ & $\sigma$ & $t(\min )$ & $A\left(\mathrm{~kg} / \mathrm{m}^{2} \times \sqrt{ } \mathbf{h}\right)$ & U (\%) \\
\hline 1 & $\mathrm{E}$ & 222.01 & 35.24 & 1.16 & 150 & 13.93 & 15.87 \\
\hline 1 & C5 & 230.18 & 35.92 & 3.40 & 120 & 15.87 & 15.60 \\
\hline 1 & $\mathrm{C} 10$ & 226.17 & 37.50 & 1.37 & 150 & 14.82 & 16.58 \\
\hline 1 & $\mathrm{C} 20$ & 223.09 & 38.30 & 0.30 & 150 & 15.14 & 17.17 \\
\hline 2 & KC5 & 220.14 & 32.96 & 0.91 & 150 & 13.03 & 14.97 \\
\hline 2 & KC10 & 225.40 & 37.51 & 1.79 & 120 & 16.58 & 16.64 \\
\hline 2 & KC20 & 224.85 & 37.57 & 0.88 & 050 & 14.85 & 16.71 \\
\hline 3 & AC5 & 226.71 & 31.61 & 0.12 & 90 & 16.13 & 13.94 \\
\hline 3 & $\mathrm{AC} 10$ & 224.35 & 32.98 & 1.36 & 90 & 16.83 & 14.70 \\
\hline 3 & $\mathrm{AC} 20$ & 236.96 & 34.64 & 0.68 & 120 & 15.31 & 14.62 \\
\hline
\end{tabular}

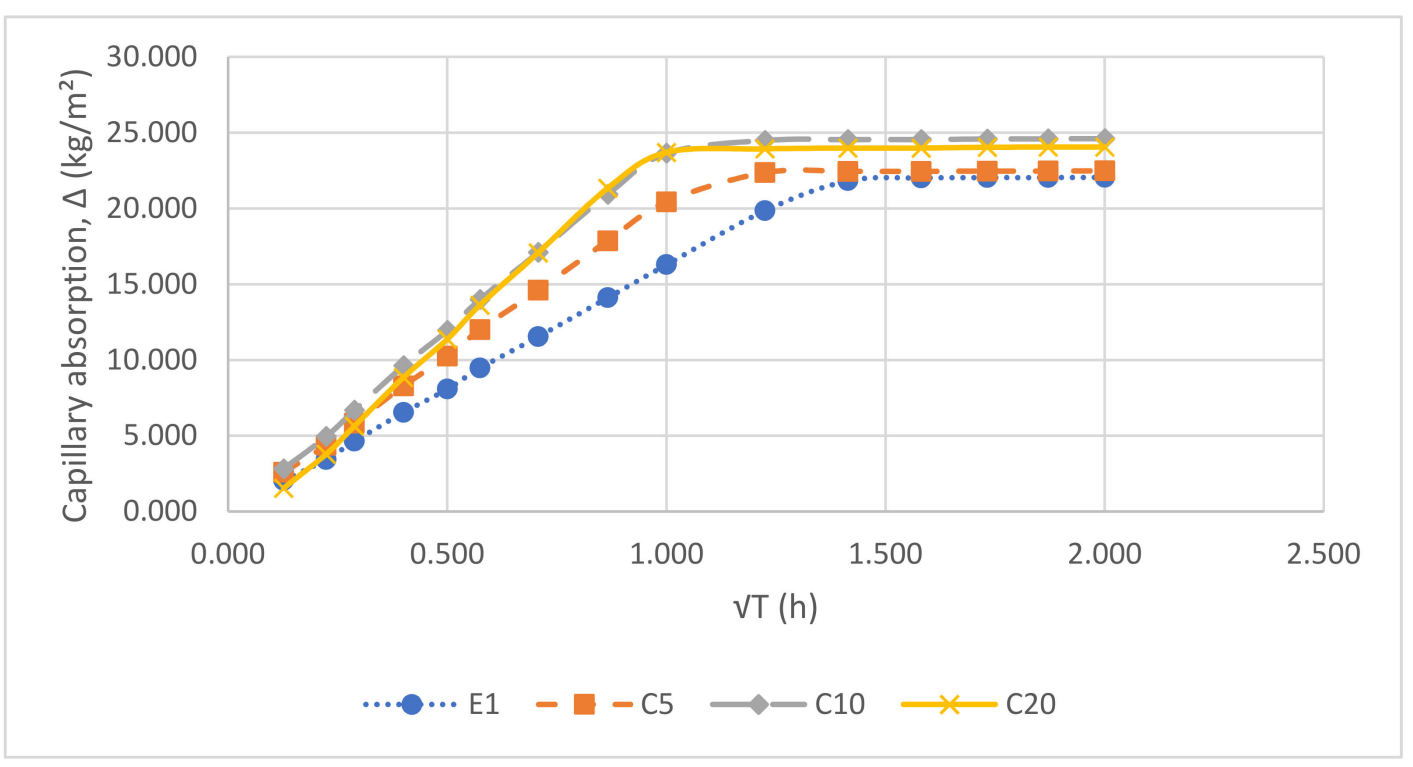

Figure 10. Capillary water absorption in Series 1 (same w/b ratio, different percentage of WPC).

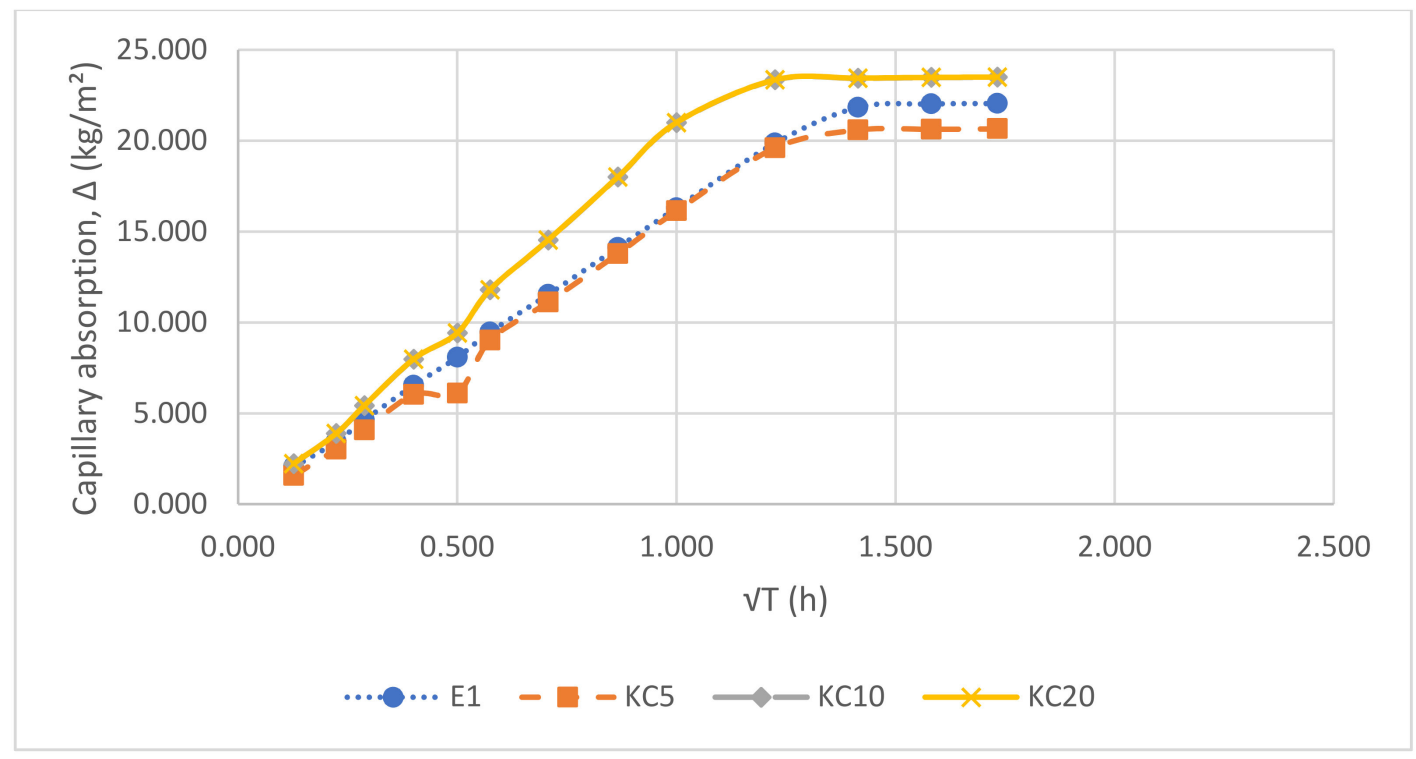

Figure 11. Capillary water absorption in Series 2 (varied $\mathrm{w} / \mathrm{b}$ ratio and percentage of WPC). 
Specimens from Series 3 (Figure 12), with the addition of AEG, did not show any significant difference. It was expected that due to increased porosity, the capillary water absorption coefficient would become higher. Hence, results obtained show different situations, referring authors to the assumption from compressive strength tests, as well. It is assumed that AEG actually did not change porosity, i.e., did not react with WPC, but with lime, resulting in greater calcification of specimens.

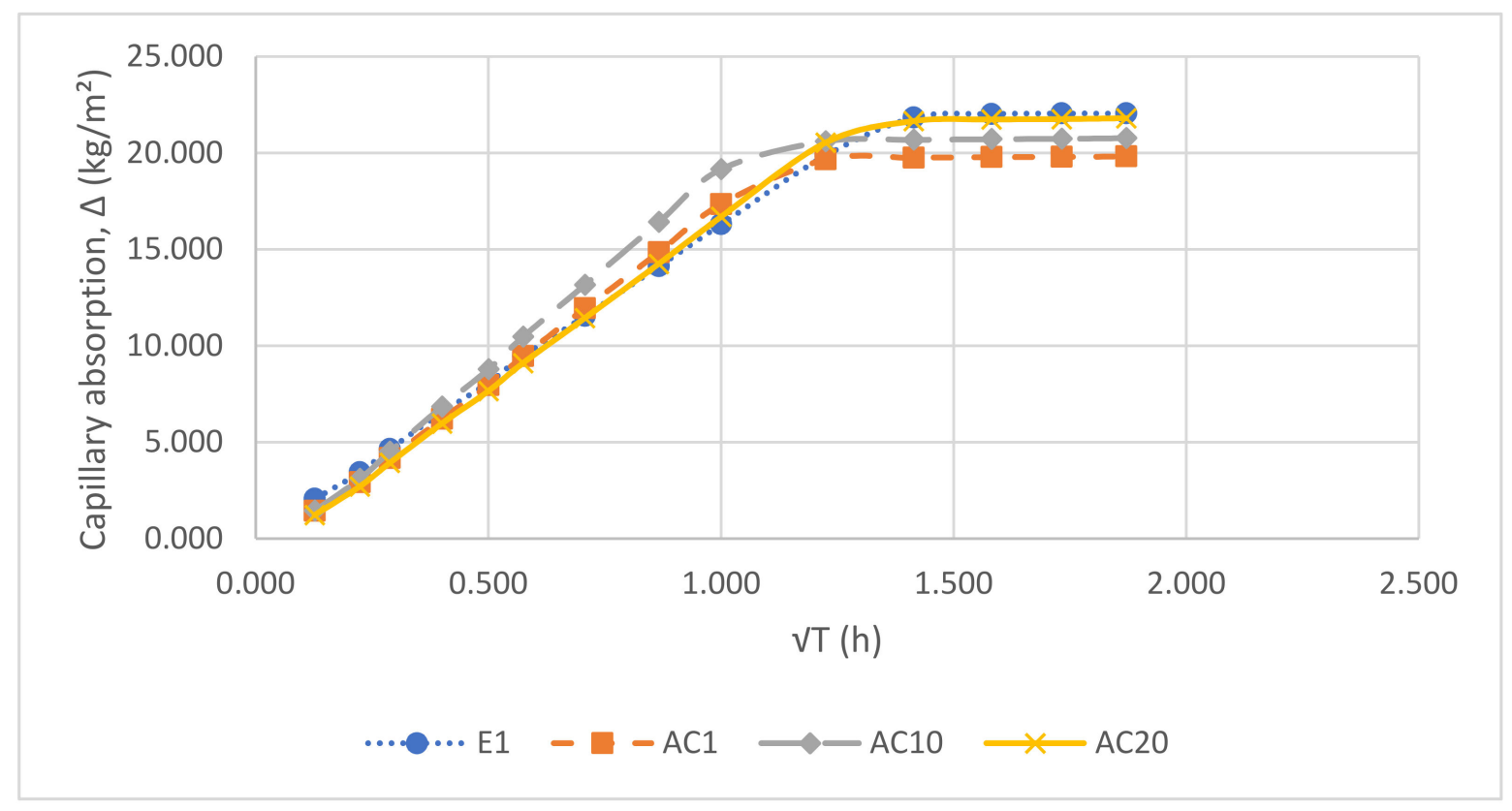

Figure 12. Capillary water absorption in Series 3 (varied $\mathrm{w} / \mathrm{b}$ ratio and percentage of WPC, $0.4 \%$ AEG agents added).

\section{Discussion}

The addition of WPC makes some difference in regard to the mechanical characteristics of specimens tested. Comparison of the results obtained from the specimens in Series 1 and 2 , where the only variable is water/binder ratio, shows that adequate dosing of water can have a major impact on the initial mechanical strengths of lime mortars with the addition of WPC. In order to maintain the same slump, the $\mathrm{w} / \mathrm{b}$ ratio was reduced as the amount of WPC was increased. This is due to the well-known fact that the strength of cement mortar is inversely proportional to the water/cement ratio [8], which is not applicable to the lime mortars due to their fine particles content. Analysing the $\mathrm{w} / \mathrm{b}$ ratio used, it could be numerically presented that this ratio is a composition of a water/lime ratio as of the reference specimen (0.875), and a standard water/cement ratio of 0.5 . Concerning this and the amount of WPC added to each specimen, the final $\mathrm{w} / \mathrm{b}$ ratio was as presented in Table 2. Results from Series 2, in regard to results from Series 1, show higher strengths as the amount of WPC increases, which was expected. It can be concluded that the addition of $20 \%$ of WPC, with a water binder ratio of 0.775 , increases compressive strength by $90 \%$ in the first 7 days, and $60 \%$ on the 28 th day.

As for the specimens from Series 3 , with a constant $\mathrm{w} / \mathrm{b}$ ratio and the addition of AEG of $0.4 \%$ to the weight of WPC added, unexpected observations occurred. AEG, as small bubbles of oxygen, was added to cement in order to improve its freeze-thaw behaviour by reducing initial stresses in the structure of the material. On the other hand, by adding AEG, the porosity is reduced. The initial idea behind Series 3 composition was to increase the porosity for specimens with WPC added, as its addition significantly reduces porosity. However, the obtained results point out different assumptions. This situation may be due to the fact that air lime mortar, as it is commonly known, hardened as a result of the transition from hydroxide $\mathrm{Ca}(\mathrm{OH})_{2}$, to carbonate $\mathrm{CaCO}_{3}$, in the presence of $\mathrm{CO}_{2}$. The obtained results indicate the possibility of reaction between AEG and lime mortar, as AEG 
are $\mathrm{CO}_{2}$ carriers. As the amount of AEG depended on the amount of WPC, AEG/lime ratio was increasing from specimen $\mathrm{AC} 5$ to $\mathrm{AC} 20$. The assumption obtained from this part of the research is that regardless of the decrease of porosity with adding AEG, its reaction with $\mathrm{Ca}(\mathrm{OH})_{2}$ actually promotes carbonation inside the specimen.

When it comes to flexural strength results, it is shown that adding WPC has a slightly positive impact as the final value is increasing with the addition of WPC. That increase is almost insignificant, so the obtained results in this research are in accordance with Arandigoyen and Alvarez [32], who concluded that $40 \%$ (by volume, approximately $26 \%$ by weight) of cement was the lower limit for improvement of flexural mechanical characteristics of lime-cement mortars. Values of flexural strength, moving from $0.125-0.455 \mathrm{MPa}$ for 7-day tests and from $0.3-0.535 \mathrm{MPa}$ for 28-day tests, are in accordance with the results of previous studies $[29,35]$. It can be noted that absolute values of flexural strengths are low, these values increase faster than those of compressive strength, which is in accordance with Ramesh, Azenha and Lourenco [36].

When it comes to capillary absorption, it can be observed that the addition of 5,10 , and $20 \%$ of WPC, does not significantly change capillary absorption capacity. It is evident from the obtained results that these results are almost the same for all mixtures, moving from $13.94 \%$ to $17.17 \%$, which is believed not to be a significant factor of different water and steam permeability.

\section{Conclusions}

In this paper, different amounts of WPC were used in order to understand how and if this addition has an influence on the mechanical and physical characteristics of lime mortars. Throughout this research, some assumptions were confirmed, whilst some findings motivated new research questions. The main findings of this research are:

- The addition of WPC to air lime mortars, of $5-10 \%$ of lime, has almost no influence on the mechanical characteristics of these mixtures. For compressive strength, results show that these small amounts actually degrade the material. Significant change happens with the addition of $20 \%$ of WPC, where both compressive and flexural strength increase. Further research should examine the mixtures with higher cement content in order to determine the optimal quantity of cement, to achieve higher strengths while maintaining the vapour permeability.

- The $w / b$ ratio has an important influence on the initial mechanical strengths of lime mortars with the addition of WPC. To achieve the same workability, the $\mathrm{w} / \mathrm{b}$ ratio decreased with the increasing amounts of additional cement. The excess of water prevents cement from gaining expected mechanical strengths, thus decreasing the overall strength of blended lime. Future research should examine the possibility of further reduction of the $\mathrm{w} / \mathrm{b}$ ratio while maintaining the required consistency using superplasticizers.

- The addition of AEG in lime mixtures, as a function of the weight of WPC, was expected to decrease mechanical strengths as a result of increased porosity. Nevertheless, this addition increased mechanical strengths, while, as authors assume, changing porosity slightly. This conclusion was reached from capillary water absorption results, as the absorption coefficient remained almost the same as of the reference mixture. The main assumption is that AEG while introducing the $\mathrm{CO}_{2}$ in the structure of the material, improves calcification and consequently increases mechanical properties of mortars, does not change porosity significantly. Different types of air-entraining agents, possible increase of the amount of AEG, and the consequence of such increase to the early strengths of the cement-blended lime mortars should be studied.

- Future research should test the adhesion of the cement-blended lime mortars to masonry units, as well as the porosity of the samples using mercury intrusion porosimetry. 
Author Contributions: Conceptualization, methodology and resources, D.V. and N.S.; validation, J.T. and R.O.-B.; investigation, all authors; writing—original draft preparation, A.K.; writing-review and editing, D.V. All authors have read and agreed to the published version of the manuscript.

Funding: This research received no external funding.

Institutional Review Board Statement: Not applicable.

Informed Consent Statement: Not applicable.

Data Availability Statement: The data presented in this study are available on request from the corresponding author.

Acknowledgments: The authors extend their gratitude to Vojislava Vasovic for her contribution in preparing tables and graphs for this text.

Conflicts of Interest: The authors declare no conflict of interest.

\section{References}

1. Friedman, D. Historical Building Construction: Design, Materials, and Technology, 2nd ed.; W. W. Norton \& Company: New York, NY, USA, 2010

2. Stanojević, D. Kreč kao istorijski material. In Zbornik radova Seminara i radionice "Kreč kao istorijski materijal", Proceedings of the Sopoćani, Serbia, 25-27 August 2014; Republički zavod za zaštitu spomenika kulture: Beograd, Serbia, 2014.

3. Van Balen, K. Carbonation reaction of lime, kinetics at ambient temperature. Cem. Concr. Res. 2005, 35, 647-657. [CrossRef]

4. Richardson, M. Carbonation of Reinforced Concrete. Its Causes and Management; Citis: Dublin, Ireland, 1988.

5. Welty, J.; Wicks, C.; Wilson, R.; Rorrer, G. Fundamental of Momentum, Heat and Mass Transfer; Wiley: New York, NY, USA, 1969.

6. Bromblet, P. Evaluation of the durability and compatibility of traditional repair lime based mortars in three limestones. Int. J. Restor. Build. Monum. 2000, 6, 513-528.

7. Lanas, J.; Alvarez, J.I. Masonry repair lime-based mortars: Factors affecting the mechanical behavior. Cem. Concr. Res. 2003, 33, 1867-1876. [CrossRef]

8. Lawrence, M. A Study of Carbonation in Non-Hydraulic Lime Mortars. Ph.D. Thesis, University of Bath, Bath, UK, 2006.

9. Papayianni, I. Design and manufacture of repair mortars for interventions on monuments and historical buildings. In Proceedings of the RILEM Technical Committee International Workshop on Repair Mortars for Historic Masonry, Delft, The Netherlands, 26-28 January 2005.

10. Valek, J.; Bartos, P. Influences affecting compressive strength of modern non-hydraulic lime mortars used in masonry conservation. In Structural Studies, Repair and Maintenance of Historical Buildings; Advances in Architecture Series VII:13; WIT Press: Southampton, UK, 2001.

11. Abdel-Mooty, M.; Khedr, S.; Mahfouz, T. Evaluation of lime mortars for the repair of historic buildings. In Structural Studies, Repairs and Maintenance of Heritage Architecture XI; WIT Press: Southampton, UK, 2009.

12. Venice Charter, International Charter for the Conservation and Restoration of Monuments and Sites. 1964. Available online: http:/ / www.icomos.org/charters/venice_e.pdf (accessed on 8 June 2021).

13. Moorehead, D. Cementation by the carbonation of hydrated lime. Cem. Concr. Res. 1986, 16, 700-708. [CrossRef]

14. Van Balen, K.; Van Gemert, D. Modelling lime mortar carbonation. Mater. Struct. 1994, 27, 393-398. [CrossRef]

15. Oliveira, M. A Multi-Physics Approach Applied to Masonry Structures with Non-Hydraulic Lime Mortars. Ph.D. Thesis, Universidade do Minho, Escola de Engenharia, Guimarães, Portugal, 2015.

16. Oliveira, M.A.; Azenha, M.; Lourenco, P.; Meneghini, A.; Guimarães, E.T.; Castro, F.; Soares, D. Experimental analysis of the carbonation and humidity diffusion processes in aerial lime mortar. Constr. Build. Mater. 2017, 148, 38-48. [CrossRef]

17. Cultrone, G.; Sebastian, E.; Huertas, M.O. Forced and natural carbonation of lime-based mortars with and without additives: Mineralogical and textural ch. Cem. Concr. Res. 2005, 35, 2278-2289. [CrossRef]

18. Peroni, S.; Tersigni, G.; Torraca, S.; Cerea, S.; Forti, M.; Guidobaldi, F.; Rossi-Doria, P.; de Rege, A.; Picchi, D.; Pietrafitta, F.; et al. Lime based mortars for the repair of ancient masonry and possible substitutes. In Mortars, Cements and Griuts Used in the Conservation of Historic Buildings; ICCROM: Rome, Italy, 1981.

19. Teutonico, J.M.; McCaig, I.; Burns, C.; Ashurst, J. The Smeaton Project: Factors Affecting the Properties of Lime-Based Mortars. APT Bull. 1993, 25, 32. [CrossRef]

20. Henriques, F.; Charola, A. Comparative study of standard test procedures for mortars. In Proceedings of the 8th International Congress in Deterioration and Conservation of Stone, Berlin, Germany, 30 September-4 October 1996.

21. Baronio, G.; Binda, L.; Saisi, A. Mechanical and physical behaviour of lime mortars after the cgaracterisation of historic mortar. In Proceedings of the International RILEM Workshop on Historic Mortars: Characteristics and Tests, Cachan, France, 31 August-2 September 2000.

22. Moropoulou, A.; Bakolas, A.; Moundoulas, P.; Aggelakopoulou, E.; Anagnostopoulou, S. Strength development and lime reaction in mortars for repairing historic masonries. Cem. Concr. Compos. 2005, 27, 289-294. [CrossRef] 
23. Lanas, J.; Sirera, R.; Alvarez, J. Compositional changes in lime-based mortars exposed to different environments. Thermochim. Acta 2005, 429, 219-226. [CrossRef]

24. Válek, J.; Matas, T. Experimental Study of Hot Mixed Mortars in Comparison with Lime Putty and Hydrate Mortars. In Proceedings of the 2nd Historic Mortars Conference HMC2010 and RILEM 203-RHM Final Workshop, Prague, Czech Republic, 22-24 September 2010.

25. Faria, P.; Martins, A. Influence of Air Lime type and Curing Conditions on Lime and Lime-Metakaolin Mortars. In Case Studies of Building Pathology in Cultural Heritage; Springer: Berlin/Heidelberg, Germany, 2013.

26. Papayianni, I.; Pachta, V. Experimental study on the performance of lime-based grouts used in consolidating historic masonries. Mater. Struct. 2014, 48, 2111-2121. [CrossRef]

27. Vejmelková, E.; Keppert, M.; Kersner, Z.; Rovnanikova, P.; Černý, R. Mechanical, fracture-mechanical, hydric, thermal, and durability properties of lime-metakaolin plasters for renovation of historical buildings. Constr. Build. Mater. 2012, 31, 22-28. [CrossRef]

28. Duran, A.; Navarro-Blasco, I.; Fernández, J.; Alvarez, J. Long-term mechanical resistance and durability of air lime mortars. Constr. Build. Mater. 2014, 58, 147-158. [CrossRef]

29. Cizer, O.; van Balen, K.; van Gemert, D.; Elsen, J. Blended lime-cement mortars for conservation purposes: Microstructure and strenght development. In Structural Analysis of Historic Construction: Preserving Safety and Significance; Taylor \& Francis Group: London, UK, 2008; pp. 965-972.

30. Arizzi, A.; Cultrone, G. Negative Effects of the use of White Portlan Cement as additive to aerial lime mortars set at atmospheric conditions: A chemical, mineralogical and physical-mechanical investigation. In Brick and Mortar Research; Manuel Rivera, S., Pena Diaz, A., Eds.; Nove Science Publisher, Inc.: New York, NY, USA, 2012; pp. 231-243.

31. Gulbe, L.; Vitina, I.; Setina, J. The Influence of Cement on Properties of Lime Mortars. Procedia Eng. 2017, 172, 325-332. [CrossRef]

32. Arandigoyen, M.; Alvarez, J. Pore structure and mechanical properties of cement-lime mortars. Cem. Concr. Res. 2007, 37, 767-775. [CrossRef]

33. Walker, P.; Lawrence, R. The impact of the water/lime ratio on the structural characteristics of air lime mortars. In Structural Analysis of Historic Construction: Preserving Safety and Significance; Fodde, D., Ed.; Taylor \& Francis Group: London, UK, 2008; pp. 885-889.

34. Duggan, A.R.; Goggins, J.; Clifford, E.; McCabe, B.A. The Use of Carbonation Depth Techniques on Stabilized Peat. Geotech. Test. J. 2017, 40, 20160223. [CrossRef]

35. Pozo-Antonio, J. Evolution of mechanical properties and drying shrinkage in lime-based and lime cement-based mortars with pure limestone aggregate. Constr. Build. Mater. 2015, 77, 472-478. [CrossRef]

36. Ramesh, M.; Azenha, M.; Lourenço, P.B. Mechanical properties of lime-cement masonry mortars in their early ages. Mater. Struct. 2019, 52, 13. [CrossRef] 